\title{
Setting the Stage: Wireless Broadband Networking in North America. (Invited Talk)
}

Presentation · January 2007

2 authors, including:

Catherine Middleton

Ryerson University

259 PUBLICATIONS 489 CITATIONS

SEE PROFILE 


\section{Setting the Stage: Wireless Broadband Networking in North America}

\section{Dr. Catherine Middleton}

Faculty of Business

Ryerson University

\section{Dr. Andrew Clement}

Faculty of Information Studies

University of Toronto

Community Wireless Infrastructure Research Project

Presented at Wireless Cities Summit, Toronto, January 23, 2007 


\section{Objectives}

- Provide an overview of wireless networking initiatives

- Highlight issues to consider as you listen to the case studies presented at the Wireless Cities Summit

- Identify desiderata for wireless initiatives 


\section{Municipal WiFi Deployments}

Municipal WiFi Systems in the United States

\begin{tabular}{|l|l|l|l|l|l|l|}
\hline $\begin{array}{l}\text { Type of } \\
\text { network }\end{array}$ & Jul & Feb & Apr & Jun & Sep & Dec \\
\hline Region/citywide & 38 & 56 & 58 & 59 & 68 & 79 \\
\hline City hotzones & 22 & 29 & 32 & 32 & 43 & 49 \\
\hline $\begin{array}{l}\text { Muni or public } \\
\text { safety use only }\end{array}$ & 28 & 32 & 35 & 35 & 35 & 36 \\
\hline $\begin{array}{l}\text { Planned } \\
\text { deployments }\end{array}$ & 34 & 59 & 69 & 121 & 135 & 149 \\
\hline Total & 122 & 176 & 194 & 247 & 281 & 312 \\
\hline
\end{tabular}

Source: muniwireless.com, summarized at

http://www.dailywireless.org/2007/01/05/time-magazine-munifi-article/ 


\section{Going Wireless: The Building Blocks}

- Organization (community group, municipality, school, university etc.) with a perceived need for networked connectivity

$\checkmark$ Purpose

- Organizational champion(s), vision for network $\checkmark$ People

- Broadband service to the organization, technical deployment of network

$\checkmark$ Backbone 


\section{Types of Broadband Networks}

- For-profit, commercial hotspots

- Community wireless networks

- Municipal broadband networks

- Public municipal wireless broadband networks 


\section{For-Profit Wireless Hotspots}

hotspot

wireless internet access

T - Mobile"HotSp •t
- Access on a fee-forservice basis

- Located in coffee shops, airports, train stations

- Operated by telecommunications companies (e.g. Bell, Telus, T-Mobile) 


\section{Community Wireless Networks}

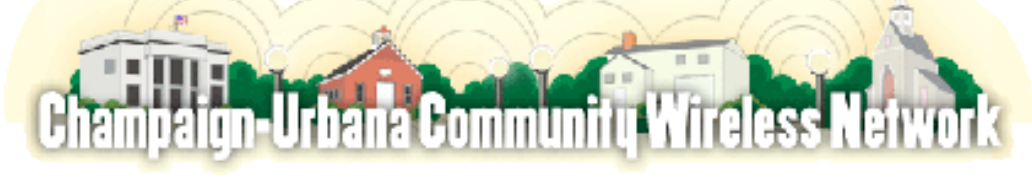

UUU wireless

nycwireless

\section{île sans fil}

- Local organizations, typically run by volunteers

- Connect local citizens to local resources

- May or may not focus on the digital divide

- Offer free alternative to commercial internet service providers, where service exists 


\section{Municipal Broadband Networks}

- Municipality provides fibre and/or wireless network

- Various models for provision, municipality may or may not own network

- Network is used for and by municipal government 


\section{Municipal Wireless Network Uses}

- Public safety, e.g. police communication

- Support for mobile workers

- Service provision, sensors, remote monitoring

- Benefits: improved service at decreased cost for municipalities
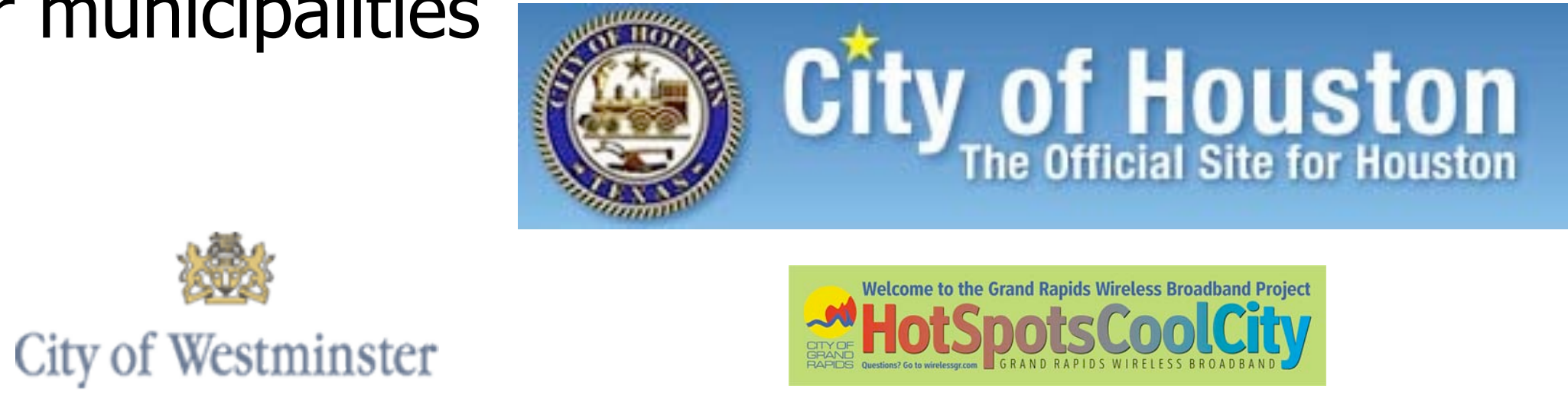


\section{Public Municipal Wireless Networks}

- Using wireless technologies, a municipality makes its existing network infrastructure available for public use, or develops infrastructure specifically for public use

- The municipality becomes an internet service provider

- This is where things get complicated... 


\section{Pre-Existing Service Level?}

- If the public municipal wireless network offers the only source of broadband connectivity to citizens:

- No competition, public infrastructure is the only option

- If there are other providers already serving the community:

- Public-private sector competition, public infrastructure overlays existing services

- Look to case studies, consider policy context 


\section{Drivers for Public Wireless Networks}

\begin{tabular}{|c|c|c|}
\hline \multirow{8}{*}{ 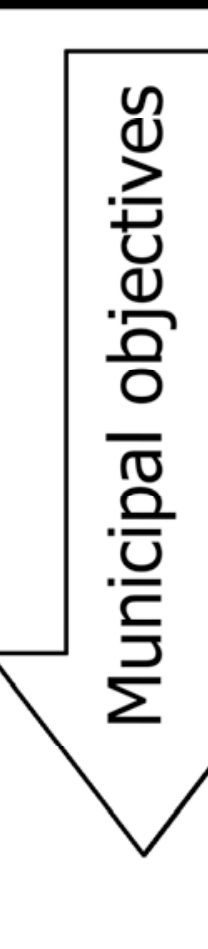 } & Espoused Benefits & \multirow{8}{*}{ 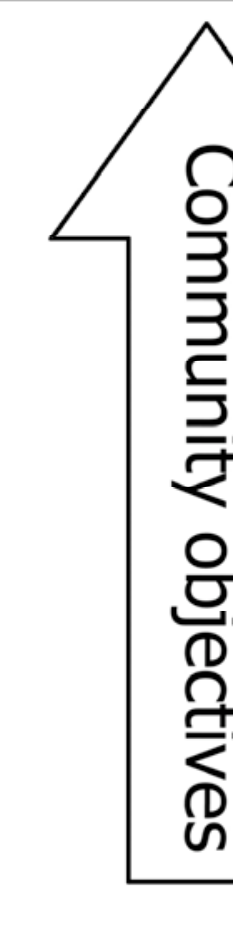 } \\
\hline & Essential service & \\
\hline & Economic development & \\
\hline & Improves efficiency & \\
\hline & Improves service & \\
\hline & Improves access & \\
\hline & Community engagement & \\
\hline & Fosters innovation & \\
\hline
\end{tabular}




\section{Public Municipal Wireless Offerings}

- What is your objective in providing a wireless network?

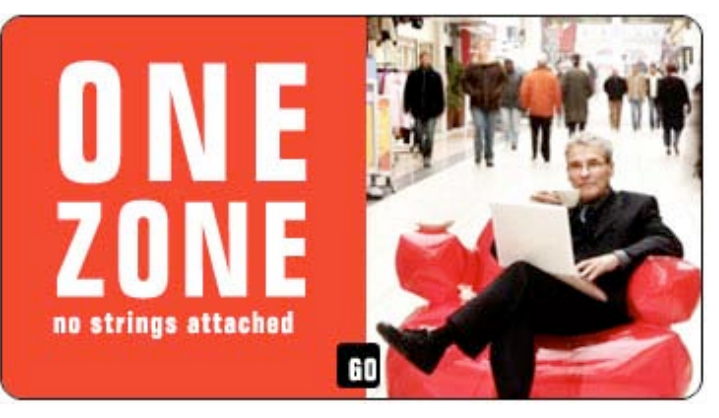

- Who are the primary users for the service?

-Where should the service be available?

- What devices should the service support?

- Pricing? Free, at-cost, commercial rates? 


\section{Why Offer Public Wireless?}

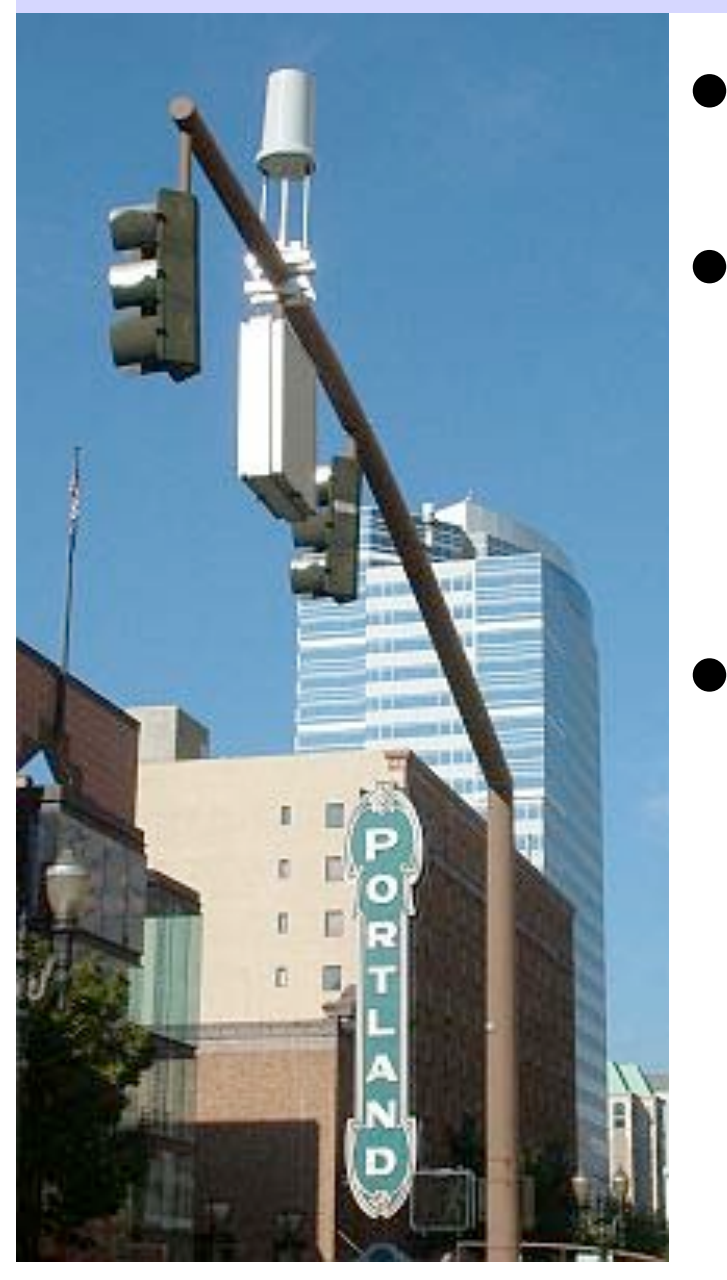

- Affordability for citizens

- Serve un- or underserved areas and offer alternative to private sector service

- Community-wide coverage offers citizens and visitors convenience, flexibility, improved access for internet and telephony services 


\section{Why Offer Public Wireless?}

- Citizen input into network development

- Open networks with no restrictions on legal usage

- Tiered pricing schemes based on bandwidth consumption

- Economic development, tourism, reputation 


\section{What to Offer?}

- Who are your primary users?

- government employees?

- local citizens?

- is this primary or secondary access?

- where will they use it? (at home? public place?)

- visitors/tourists
- What type of coverage do you want?

- Hotspots

- Wide area "cloud"

- Portable service

- moves with user but does not support mobility

- Mobile service

- can be used in vehicles

- Outdoor and Indoor? 


\section{What type of technology?}

- How to provision network "backhaul"?

- Should the network be based on WiFi/WiMax standards or cellular telephony standards?

- What device(s) will be used to access the network and services?

- laptop? PDA/portable PC? mobile phone?

- Choice of vendor, ownership of network, partnerships? 


\section{Recap: Key Questions for Muni WiFi}

- Why do you want to develop a wireless network for your organization?

- What is the purpose of the network?

- Who will the network serve?

- Where is network coverage needed?

- How will you provision the network?

- What is the business model? 


\section{Local case: Toronto Hydro Telecom}

- City-owned utility

- Largest WiFi zone in Canada

- Built on existing extensive fibre back-bone

- Ubiquitous service, up to 7Mbps

\section{What is the best approach?}




\section{Commercial competitor (current model)}

Capital investment:

- $\$ 2 \mathrm{M}$ for first phase, $\sim \$ 56 \mathrm{M}$ full coverage

Pricing (after 6 month free period):

- $\$ 29 / \mathrm{mo}$

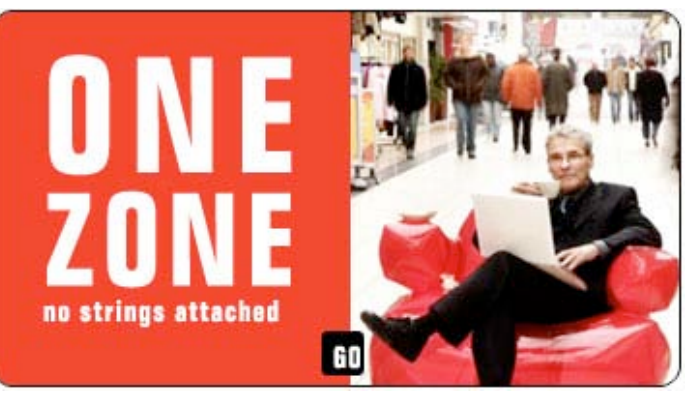

$\$ 348 / y r+$ taxes

Competitors:

- Rogers (cable)/Bell Sympatico (DSL): \$520/yr - \$560/yr

Main benefits:

- Attracts businesses, tourists and investment to city

- No cost to taxpayers, profits shared with City ( 1 year pay-back, with $1 \%$ share)

- $30 \%$ savings to subscribers

Sources: onezone.ca,rogers.com, sympatico.ca, THT presentations, Apr 27 \& Sep 6, 06 


\section{Public Utility (alternative model)}

Operating costs:

Average annual household cost:

Funding options:

- property taxes

- utility bill

Main benefits:

- Cost savings ( $\$ 300-400 / y r)$ for $60 \%$ of households now with broadband

- Eased access for $25 \%$ of households now without internet access

\section{How to choose between such models?}

Note: These rough calculations are our own based on publicly available information. Sources: Technical details - onezone.ca, THT presentations, April 27,06 \& Sept 6, 06. 


\section{Desiderata - for public wireless Internet}

1. Ubiquitous

2. Affordable

3. Reliable

4. Healthy

5. Secure

6. Widely Useful

7. Cost Effective

8. Convenient and Ready-to-Hand 


\section{Desiderata (2)}

9. Open

10. Neutral and Non-Discriminatory

11. High Quality

12. Privacy Enabling

13. Accessible and Usable

14. Communicative Commons Enabling

15. Civically oriented

16. Accountable and Responsive 


\section{Ubiquitous}

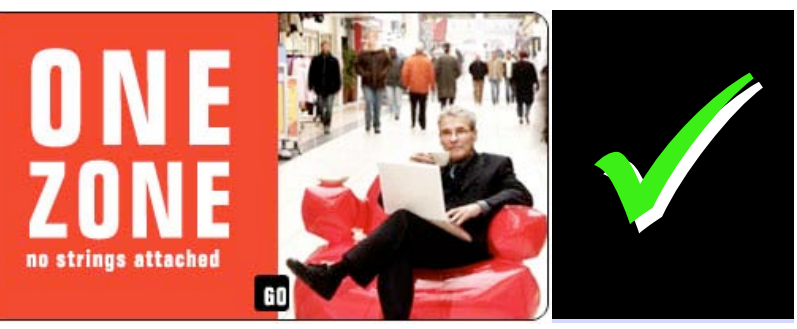

Service coverage should include every household, business, organization, public space, tourist destination, and public transit corridor in the network's coverage area, within the limits of what is technically feasible.

Wireless contributes to enlarging service coverage to areas that are not easily reachable by wireline, and enabling the development of new services. 


\section{Open}

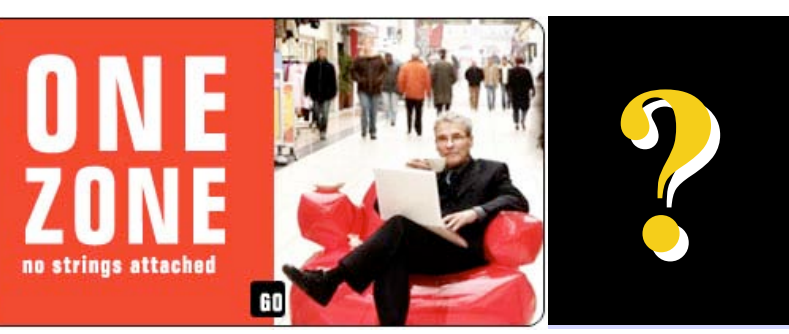

\section{INEC Declaration on Open Networks:}

“3. Infrastructures should be 'open', meaning they are wholly open for any market entity to provide its services on a totally equal basis, free to compete with any other market entity.... The open nature of such infrastructures extends to:

a. Technology: the infrastructure must be compatible with other networks, whereas the technical protocols have been made available or known to all;

b. Functionality: there should be no barriers or limitations in the connectivity between one end-user and another

c. Finance: the costs of infrastructure usage should be non-discriminatory and stimulate fair competition

d. Organization: all providers shall have equal opportunities to offer their services to their clients or prospective clients"

http://www.smartcommunity.nl/the_declaration 


\section{Accountable \& Responsive}

Transparency in policy development and operations. Mechanisms of governance and citizen oversight to ensure that the service and its operator are responsive to citizen input and needs. 


\section{Espoused Benefits of Public Wireless}

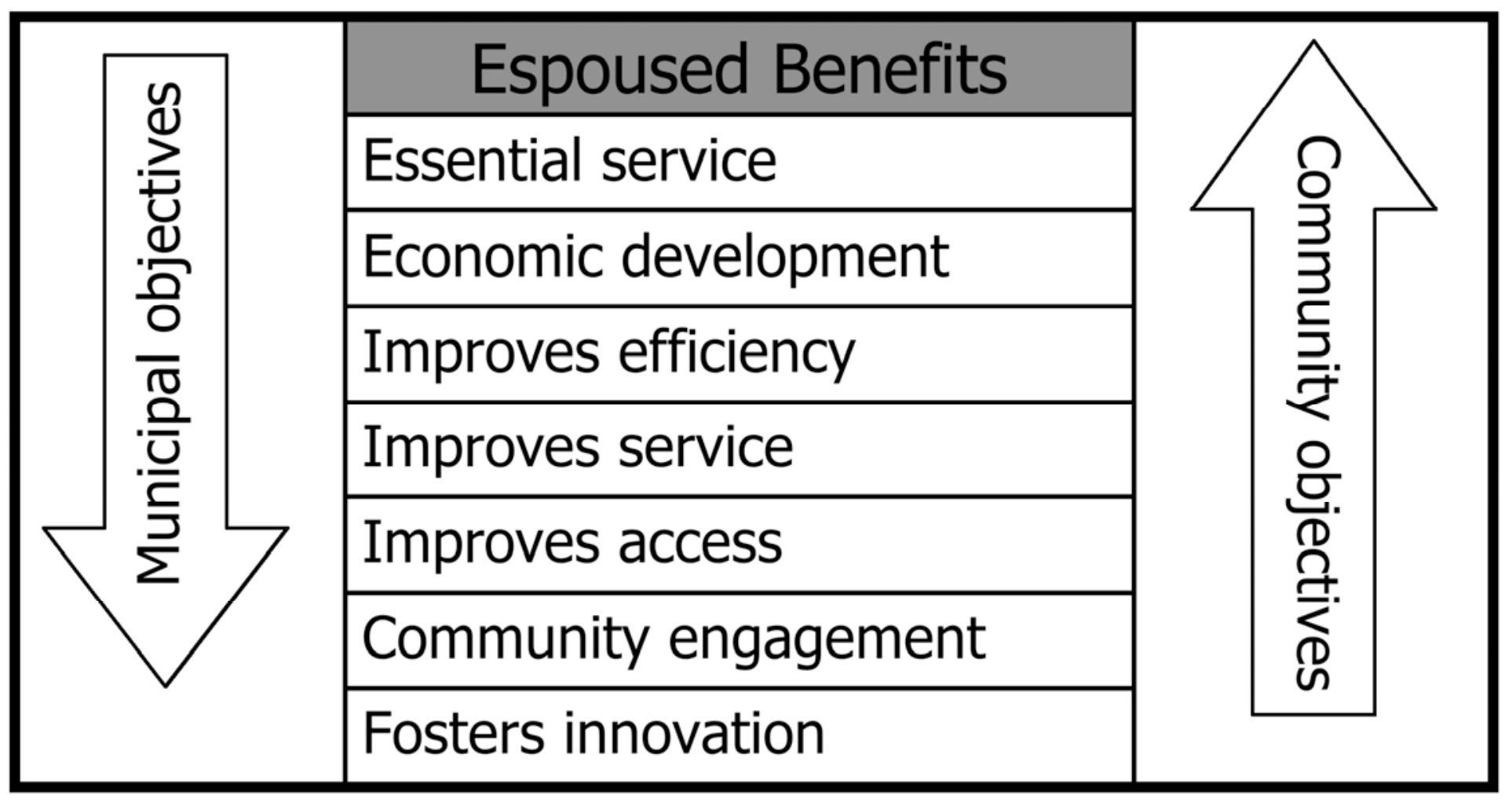




\begin{tabular}{|l|l|}
\hline Espoused Benefits & Desiderata \\
\hline Essential service & $\begin{array}{l}\text { 1. Ubiquitous } \\
\text { 2. Affordable }\end{array}$ \\
& $\begin{array}{l}\text { 3. Reliable } \\
\text { 4. Healthy } \\
\text { 5. Secure }\end{array}$ \\
\hline Economic development & $\begin{array}{l}\text { 6. Widely useful } \\
\text { 9. Open } \\
\text { 10. Neutral and non-discriminatory }\end{array}$ \\
\hline Improves efficiency & $\begin{array}{l}\text { 7. Cost effective } \\
\text { 8. Convenient and ready-to-hand } \\
\text { 9. Open } \\
10 . \text { Neutral and non-discriminatory }\end{array}$ \\
\hline
\end{tabular}




\begin{tabular}{|c|c|}
\hline Espoused Benefits & Desiderata \\
\hline Improves service & $\begin{array}{l}\text { 9. Open } \\
\text { 10. Neutral and non-discriminatory }\end{array}$ \\
\hline Improves access & $\begin{array}{l}\text { 1. Ubiquitous } \\
\text { 13. Accessible }\end{array}$ \\
\hline $\begin{array}{l}\text { Community } \\
\text { engagement }\end{array}$ & $\begin{array}{l}\text { 14. Communicative commons enabling } \\
\text { 15. Civicly oriented } \\
\text { 16. Accountable and responsive }\end{array}$ \\
\hline Fosters innovation & $\begin{array}{l}\text { 1. Ubiquitous } \\
\text { 6. Widely useful } \\
\text { 9. Open } \\
\text { 10. Neutral and non-discriminatory }\end{array}$ \\
\hline
\end{tabular}




\section{'Enabling' Conditions}

- Access to high bandwidth backhaul

- Open spectrum policies

- Business models to suit local context (geography, existing infrastructure, political environment, support of local community) 


\section{Conclusions}

- Desiderata as a preliminary effort to define what public wireless infrastructures should/could look like

- Need to consider best means for achieving the desired outcomes

- Shift debate from ideological grounds to serving intended beneficiaries - the public 


\section{Thank you!}

\section{CWIRP.ca}

These slides are available at:

www.cwirp.ca/files/wireless summit.pdf

This research has been supported by a grant from Infrastructure Canada. The views expressed are our own. 